\title{
Analysis of the Factors Affecting the Payment Collection of Private Enterprises
}

\section{Ying Kong*}

Tongling University, Tongling City 244061, Anhui Province, China. E-mail: 2723525022@qq.com

\begin{abstract}
Payment collection is not only a form of capital flow, but also a business model in sales. Some enterprises are selling goods but not immediately settle accounts; they allow customer write IOUs and later pay regularly. Does the customer actually pay on a regular? As it turns out, only a small percentage of customers can make regular payments. It is a difficult problem that many private enterprises do not want to face but have to face. The problem of payment collection directly affects the capital flow and turnover of enterprises, and even leads to the paralysis of enterprises. It is of great significance to analyze the factors affecting the payment collection of private enterprises. This paper first analyzes the current situation of the payment collection and the factors affecting the payment collection, and finally gives the countermeasures ${ }^{[1]}$.
\end{abstract}

Keywords: Enterprise; Payment Collection; Problem

\section{Analysis of the current situation of payment collection}

In order to increase sales or reduce inventory, many enterprises use the sales method of selling products to customers first and then asking customers to pay by installments. While they pay attention to sales volume, they tend to ignore customers' late payment ${ }^{[2]}$. In real life, the ratio between the paid-in sales amount and the total sales income of the enterprise, that is, the repayment rate, is not optimistic, and some of them even become bad debts, bringing bad debts losses to the enterprise. According to relevant data, Hangzhou Binjiang Real Estate Group Co., Ltd., one of the top 500 private enterprises in China, had a return rate of less than $30 \%$ in 2018. The low return rate has brought a very negative impact on the company. Therefore, the problem of payment collection has become one of the serious problems of the enterprise, and the business personnel of the enterprise are often confused about it.

\section{Analysis of influencing factors}

The problem of payment collection is universal, and there must be some reasons for its existence. So what are the factors that affect the collection of money? The following analysis is made from the perspectives of enterprises and customers.

\subsection{Perspective of enterprises}

\subsubsection{Imperfect payment collection system}

Many enterprises relatively pay more attention to the product sales, because it seems to the customer that product sales job means good quality of products. In other words, the sales to a certain extent influence the customer choice,

\footnotetext{
Copyright (C) 2020 Ying Kong

doi: $10.18282 /$ ff.v9i2.865

This is an open-access article distributed under the terms of the Creative Commons Attribution Non-Commercial License

(http://creativecommons.org/licenses/by-nc/4.0/), which permits unrestricted non-commercial use, distribution, and reproduction in any medium, provided the original work is properly cited.
} 
affect earnings. The enterprises give business a lot of encouragement in the aspect of sales promotion ${ }^{[3]}$. For example, the salary of sales staff is measured by sales volume or employees are evaluated on the basis of personal annual sales, and enterprises make various system related to boost sales. Many enterprises, while formulating the sales promotion system, ignore the customers' settlement of these unpaid products in the later period, so the problem of payment collection of enterprises is put on hold, resulting in a very low rate of payment collection.

\subsubsection{Imperfect after-sales service}

In order to increase sales and save time to serve more new customers, business people sell products on credit to customers and then ignore the after-sales service. Business personnel of the enterprise should not blindly focus on the promotion of sales volume, but consider the overall interests of the enterprise. In the process of using the product, customers will often have questions related to the product, but no one can be found to answer them, especially when they are in trouble ${ }^{[4]}$. In this case of extremely inconsiderate after-sales service, customers will have an extremely poor shopping experience. After all, customers' ideal state is to get "nanny-style" and complete service or even "one-to-one" service. Once there is a huge contrast with their ideal state, it will undoubtedly affect customers' later settlement. All business personnel concentrate on the sales of the credit system, at the same time, they also need to offer channels that customers can get after-sales service, which also provides enterprise business personnel with a chance of pressing for payment. When customers' problems have been to solved, their mood is supposed to be good, and business personnel grasp this chance to remind them to pay the bill, the probability of success is higher than usual. Therefore, more and better after-sales service should be provided for customers ${ }^{[5]}$.

\subsubsection{Poor quality of the product itself}

Quality is the lifeline of an enterprise, the source of its life, determining the market of tomorrow. If there is a quality problem in the products sold by the enterprise, the products will always go wrong every once in a while when the customers are using them. Customers even need to carry out tedious maintenance, and suspect that they have bought a fake product. In this case, no one is willing to settle the payment for the product. Even if they are willing to do, they are not willing to settle the payment in the short term. In this case, how can the problem of payment collection be solved smoothly? This is similar to the way that when a worker builds a house for someone else, the boss always withholds part of the worker's salary, in case someone can't come to repair the house if it goes wrong later. If customers always encounter failures in the process of using the product, they will not be willing to pay the total amount of the product in case they cannot find someone to solve the problem in the future. In this case, bad debts are likely to be generated. Product's quality is the key factor affecting enterprise's payment collection, and it is worthy of enterprise's attention ${ }^{[6]}$.

\subsection{Perspective of customers}

\subsubsection{Insufficient credit}

Nowadays, credit deficiency is not an isolated case, which exists in every industry and every field. Once people break faith with others, bad effects are in all directions. Credit is the bridge of social economy, lack of which in economic life brings difficulties to a lot of things, let alone payment collection. In the case of imperfect payment collection system, efforts of the enterprise business personnel are probably of no avail encountering the lack of credit. Lack of credit is also an important factor affecting payment collection.

\subsubsection{Insufficient funds}

It is also possible that customers will be "strapped for cash" at the time of the settlement, especially for affiliates. After all, a lot of things are unknown. The affiliate may encounter an emergency to deal with, or happen to have a difficult capital turnover, and misappropriate the funds originally intended to be used for payment, which will definitely affect the payment. However, in this case, as far as the customer is concerned, the settlement may only be a matter of time, but for the enterprise, it is still a problem of payment collection to be solved. 


\section{Countermeasures}

Through the analysis of the factors affecting payment collection from the perspectives of enterprises and customers, the reason for the difficult payment collection is clear. Countermeasures can be carried out in the following two aspects.

\subsection{Perspective of enterprises}

\subsubsection{Pay more attention to the issue of payment collection}

In order to break the original idea of paying too much attention to sales volume, business personnel should pay more attention to the issue of payment collection through a variety of ways. Business personnel should understand that sales and payment collection are equally important, and adverse payment collection will affect the capital turnover of enterprises, which will have extremely negative impact on enterprises. A reward and punishment system should be implemented for payment collection to motivate and encourage business personnel to pay attention to the issue of payment collection, so as to make the issue of payment collection deeply rooted in people's hearts, and prevent business personnel from using credit sales system for customers of paying on delivery, which will lead to the problem of payment collection in the later stage ${ }^{[6]}$. Enterprises can train business personnel on payment collection skills, which is still very important. To some extent, it can determine whether business personnel can successfully urge payment. To achieve a balance between sales and payment collection is more likely to bring more benefits to the enterprise and avoid some unnecessary problems.

\subsubsection{Establish a sound payment collection system}

The higher the sales repayment rate is, the better the enterprise's sales control and capital control. While developing the sales system, enterprises should not ignore the payment system. For example, in the implementation of credit sales system, it is necessary to first make clear the customer's credit, to see whether they have a record of broken promises, and then consider whether the customer can use credit sales system to prevent bad debt losses. The business personnel should actively pursue the payment, as far as possible to reduce the problem of payment collection. If the customer fails to fulfill the required payment amount within the corresponding period, business personnel may take measures such as raising the price on the basis of the original price.

\subsubsection{Strictly control product quality}

High quality products are the core to increase product sales and solve the problem of payment collection. The high quality product can earn the customers' trust, so that the product has the good public praise. Good reputation not only attracts more regular customers, but also allows them to bring in new customers, forming a good cycle, so the product sales naturally increase. What the enterprise sells is not only the product, but also responsibility, which can be reflected in the product quality. What customers pursue is reassurance, so they are willing to pay for the product only if the product is of good quality. In this way, payment collection is not a problem. It is important for enterprises to focus on the quality of their products. After all, they can kill two birds with one stone - as the quality of their products improves, so does the sales volume and the return rate ${ }^{[7]}$.

\subsection{Perspective of customers}

\subsubsection{Improve the credit rating}

Credit is a measure of a person, but the lack of credit is a common problem. The lack of credit may lead to the paralysis of the whole social system. People with low credit may be restricted in many aspects in the future, the most direct of which is the impact on personal loans. The lack of credit is harmful and unprofitable for people. For example, the amount of Ant Check Later is actually the embodiment of credit, and the high credit degree means the high amount of Ant Check Later. For another example, the credit score of Sesame Credit can determine whether certain items can be lent free of charge or not ${ }^{[8]}$. Therefore, to improve their own credit should not only be reflected in the settlement of this aspect, but also in all aspects of life. High credit is certainly good for individuals. It is quite necessary for customers to 
improve their own credit.

\subsubsection{Pay attention to the issue of payment settlement}

Customers' behaviour of enjoying the product but having a late payment is taking no count of payment settlement. Lack of funds and other reasons may be an excuse, if there is enough funds, how can it be misappropriated to do other things? Attention is also a reflection of customer attitude. Only when customers pay attention to the issue of payment, the problem of payment settlement can be solved smoothly ${ }^{[9]}$. Both sides should be considerate of each other: enterprises should provide customers with superior products and services; customers also should understand the difficulties of enterprises. After all, the receivable influences enterprises' capital flow. Low rate of return is likely to make the enterprise get into trouble, and even lead to disordered operation of the enterprise for a long time. Customers should pay more attention to this problem and settle accounts at the appointed time ${ }^{[10]}$.

\section{Conclusion}

The existence of the problems of payment collection is not a problem of either the enterprise or the customers, so neither the enterprise nor the customers can be blamed alone. A solution to the problem requires joint efforts on both sides. Enterprises provide customers with high-quality products and thoughtful services, and customers should understand the difficulties of enterprises. Both sides attach importance to this rare cooperation opportunity, so as to achieve the goal of win-win results. From this, enterprises gain direct benefits, while customers gain a comfortable shopping experience. If both parties can give more consideration to each other, many problems can be solved smoothly and the problem of payment collection can be easily solved.

\section{References}

1. Li X. The study on the optimization of accounts receivable management system: Taking Company A as an example (in Chinese). China Collective Economy 2020; (2): 104-106.

2. Cui Z. The solution of the dealer's collection problem (in Chinese). China Animal Husbandry Bulletin 2008; (5): 54-55.

3. Zhang X. A brief analysis of the reasons for the formation of accounts receivable and management countermeasures (in Chinese). Inner Mongolia Coal Economy 2019; (19): 106+112.

4. Zeng L. A brief discussion on the problems and countermeasures of enterprise accounts receivable management (in Chinese). Accountant 2019; (11): 38-39.

5. Zhao M. Analysis of factors affecting the return of private enterprises: Taking Shenglong Electric as an example (in Chinese). Technology and Economic Guide 2018; 26(15): 215+197.

6. Zhang T, Gu F. Analysis of real estate company sales collection (in Chinese). Cooperative Economy \& Science 2017; (19): 91-94.

7. Deng G. Risks and countermeasures of sales collection of Company Z (in Chinese). Knowledge Economy 2015; (10): 105.

8. Yan Y. A brief analysis of the collection of money in design engineering companies (in Chinese). China Township Enterprises Accounting 2014; (10): 139-140. doi: 10.3969/j.issn.1004-8480.2014.10.070.

9. Qiao X. Discussion on the difficulty of receivables collection and its countermeasures (in Chinese). Journal of Wuxi Vocational and Technical College 2009; 8(2): 90-92.

10. Peng G. Analysis on the reasons and countermeasures of the difficulty in collecting payment (in Chinese). Modern Economic Information 2013; (17): 211. doi: 10.3969/j.issn.1001-828X.2013.17.177. 